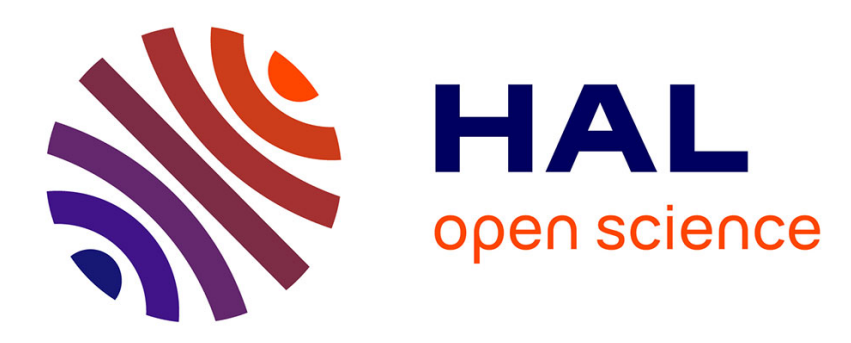

\title{
Improved solution resistors for high voltage applications
} J.M. Marks

\section{- To cite this version:}

J.M. Marks. Improved solution resistors for high voltage applications. Revue de Physique Appliquée, 1979, 14 (6), pp.683-684. 10.1051/rphysap:01979001406068300 . jpa-00244647

\section{HAL Id: jpa-00244647 https://hal.science/jpa-00244647}

Submitted on 1 Jan 1979

HAL is a multi-disciplinary open access archive for the deposit and dissemination of scientific research documents, whether they are published or not. The documents may come from teaching and research institutions in France or abroad, or from public or private research centers.
L'archive ouverte pluridisciplinaire HAL, est destinée au dépôt et à la diffusion de documents scientifiques de niveau recherche, publiés ou non, émanant des établissements d'enseignement et de recherche français ou étrangers, des laboratoires publics ou privés. 


\title{
Improved solution resistors for high voltage applications
}

\author{
J. M. Marks \\ Department of Structural Chemistry, The Weizmann Institute of Science, Rehovot, Israel
}

(Reçu le 11 avril 1978, révisé le 23 février 1979, accepté le 27 février 1979)

\begin{abstract}
Résumé. - Il est possible d'augmenter la vie des résistances pour hautes tensions formées par des solutions de sulfate de cuivre se trouvant dans des tuyaux de PVC en les rendant aussi longues que possible. Les résultats expérimentaux confirment que la durée utile des résistances est proportionnelle au carré de la longueur du tuyau comme prédit la théorie.

Abstract. - It is possible to increase the useful life of high voltage copper sulphate solution resistors contained in PVC tubing by making them as long as is practical. Experimental results confirm that their useful life varies approximately as the square of the length in agreement with the theory.
\end{abstract}

Cheaply constructed resistors for high voltage applications can be made from P.V.C. flexible tubing filled with the appropriate acqueous solution of copper sulphate in deionised water with copper electrodes inserted in either end [1], and wound spirally around a vertical cylinder. In the Neptune pulsed electron beam accelerator [2] at the Weizmann Institute a pair of these resistors are immersed in the oil of the LC generator tank and serve as charging resistors for the capacitor bank which is connected through them to a dual polarity $60 \mathrm{kV}$ power supply. Their resistance is about $4 \mathrm{M} \Omega$ and they conduct for each charging 0.275 coulomb and dissipate 9 kilojoules of heat with a peak of 900 watts. It was observed that the bank could only be charged through these resistors a limited number of times before the increase in their resistance and thus the time to charge became unacceptably long [3] and furthermore this occurred much sooner for the resistor whose lower electrode was connected to the positive supply. This can be explained in terms of the electrolytic process whereby copper ions drift to the negative electrode and are deposited on it or in its vicinity as a suspension of a black copper compound. Eventually this region becomes depleted of sulphate ions and tends to form a high resistance in series. When the negative electrode is the lower one this tendency is opposed by convection due to resistive heating and is thus delayed. When, however, the negative electrode is uppermost convection cannot occur and the life of the resistor is much shorter. At the positive electrode the solution becomes more concentrated and conductive and acquires a blue-green colouration. Simply, the problem of asymmetry is overcome by arranging that for both these resistors the positive electrode is uppermost and thus the current flow is in the same direction in both.

That further increase in their useful life is possible can be predicted from the following theory. The useful life of the resistor is clearly related to the time for the ions to drift the length of the resistor. This time is given by :

$$
t=b L / v
$$

where $b$ is an empirical constant and $v$ is some average drift velocity of the ions. Now the drift velocity is given by :

$$
J=I / A=n e v
$$

where $J$ is the current density, $I$ the current, $A$ the cross-section area of the resistor, $n$ the number of ions per unit volume and $e$ the electronic charge. Because we are dealing here with very weak solutions the copper sulphate is completely ionised and therefore $n$ is proportional to $c$, the concentration of the solution, according to the following relation :

$$
n=c N_{0} / M
$$

where $N_{0}$ is Avogadro's number and $M$ is the molecular weight of copper sulphate. Now the resistivity, $\rho$, for a resistor of resistance, $R$, and length, $L$, is given by :

$$
\rho=R A / L \text {. }
$$

From the graph in [3] for copper sulphate solutions we have the empirical relationship :

$$
c=f / \rho^{1.2}
$$


where $f$ is an empirical constant which depends on temperature. Finally we have for the voltage $V$ across the resistor :

$$
V=I R
$$

Combining the above relations we get :

$$
t=\left(b f N_{0} e L^{2.2}\right) /\left(M V A^{0.2} R^{0.2}\right) .
$$

That is, the useful life is strongly dependent on the length of the resistor and it should therefore be possible to extend its life for a given value of resistance by making it as long as possible. This relation was confirmed experimentally as follows. Four solution resistors with nominally equal initial resistances of 4.49, 3.87, 3.26 and $2.5 \mathrm{M} \Omega$ and with lengths 1004 , 449,310 and $106 \mathrm{~cm}$ respectively were made from tubing of bore $1.27 \mathrm{~cm}$ and were wound on cylindrical formers of o.d. $8.8 \mathrm{~cm}$. The upper electrodes were connected in parallel to a positive $1.2 \mathrm{kV}$ power supply while the lower electrodes were grounded individually through ordinary $1 \mathrm{k} \Omega$ resistors, the voltages on which were connected sequentially to a chart recorder by means of an electronically pulsed uniselector. Thus was obtained a continuous record of the variation of the resistances over a period of nearly two days. In figure 1 the reciprocals of these resistances are plotted as functions of time normalized to the initial resistance of the longest resistor

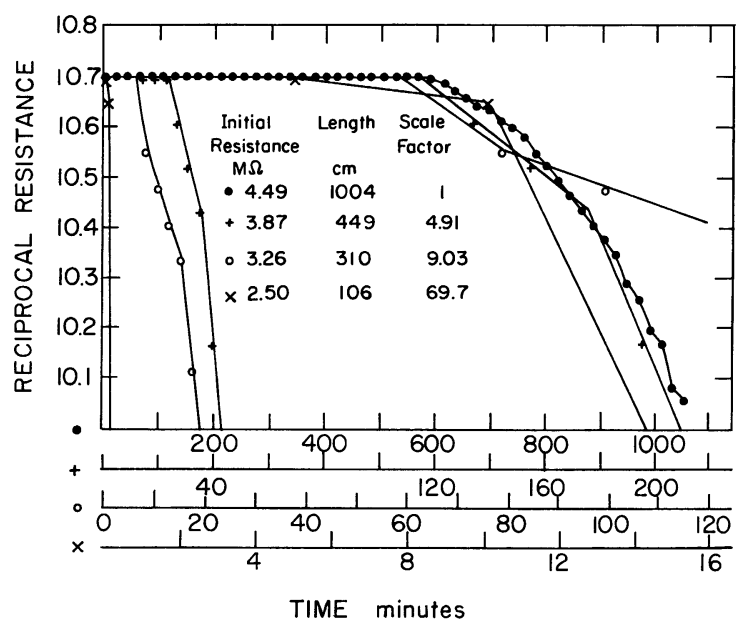

Fig. 1. - Reciprocal resistance of four resistors of different lengths plotted as functions of time. The ordinates are normalised and plotted on an arbitrary scale. The scale factor is

$$
\left(L_{0}^{2.2} R^{0.2} / L^{2.2} R_{0}^{0.2}\right)
$$

where $L$ and $R$ are the lengths and the initial resistances respectively and « $0 »$ refers to the longest resistor. and additionally with the time scales expanded relative to it by the factor $\left(L_{0}^{2.2} R^{0.2} / L^{2.2} R_{0}^{0.2}\right)$ where the subscript $~ " 0$ » refers to the longest resistor. Thus the resistors are seen to remain comparatively stable for durations proportional to those predicted by (7). In the case of the longest resistor the total charge passed through it up to the time its resistance increased by $10 \%$ is equivalent to charging the capacitor bank 70 times.

To increase the lengths of the capacitor bank resistors without increasing their overall dimensions they were constructed of $10 \mathrm{~m}$ of tubing of bore $4.8 \mathrm{~mm}$ in place of $3 \mathrm{~m}$ of bore $1.27 \mathrm{~cm}$. This design is illustrated in figure 2 where the tubing is shown

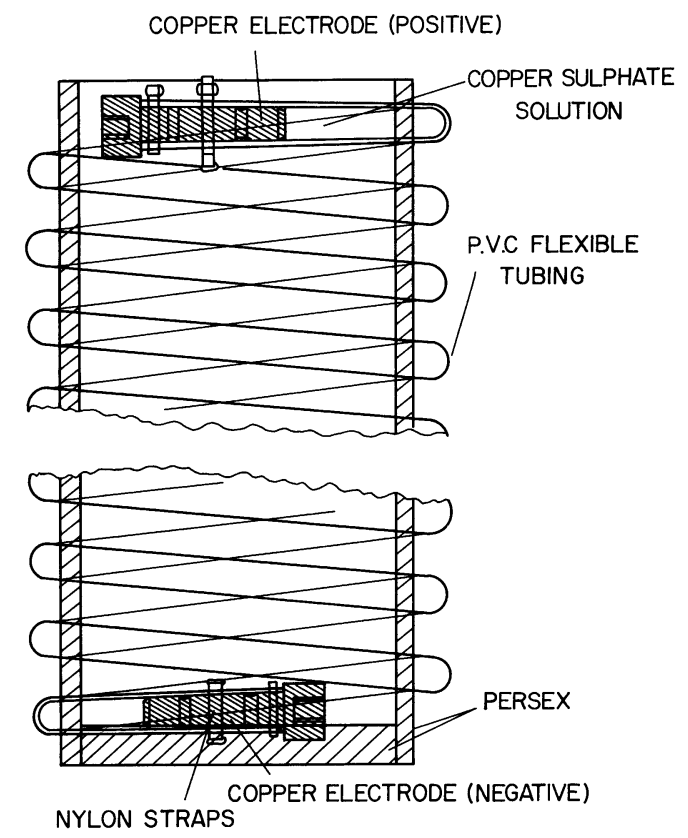

Fig. 2. - Construction of spirally wound copper sulphate solution resistor made from PVC tubing.

expanded gradually over half a turn at either end in order to use electrodes of $1 \mathrm{~cm}$ diameter. Note that the resistor must contain sufficient volume to absorb the deposited energy without excessive rise in temperature which, for these new resistors, would be $12^{\circ} \mathrm{C}$ if heat loss is neglected during the charging time of 50 seconds. This is acceptable for the duty cycle of the accelerator of about one hour. The predicted improvement, of about 10 times, in the life of these resistors was consequently observed when they were installed on the accelerator.

Thanks are due to Y. Shimoni who constructed the apparatus.

\section{References}

[1] Martin, J. C., Nanosecond Pulse Techniques (A.W.R.E., Aldermaston) 1970.

[2] Harris, N. W. and Milde, H., IEEE Trans. Nucl. Sci. NS-23 (1976) 1470.

[3] Bishop, A. E. and Edmonds, G. D., Plasma Phys. 7 (1965) 423. 